\title{
Correction: Signally via the osteopontin and high mobility group box-1 axis drives the fibrogenic response to liver injury
}

Arriazu E, Ge X, Leung T-M, et al. Signally via the osteopontin and high mobility group box-1 axis drives the fibrogenic response to liver injury. Gut 2017;66:1123-37. doi: 10.1136/ gutjnl-2015-310752.

Panel B in figure 6 is incorrect and has been removed. The updated figure and legend should be:
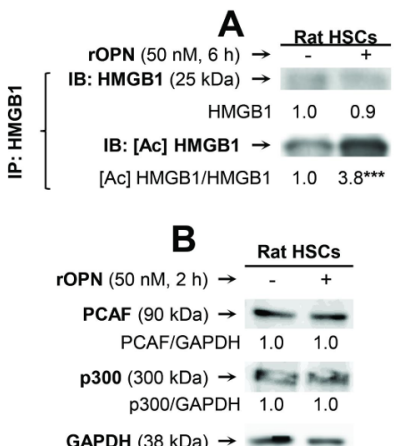

GAPDH $(38 \mathrm{kDa}) \rightarrow-$
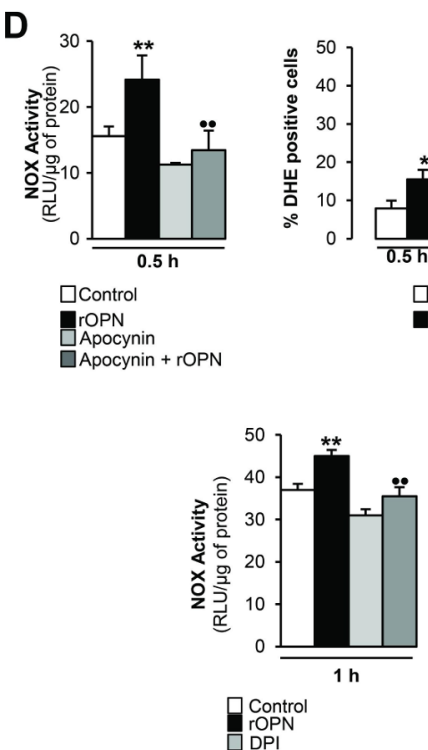

DPI

$\square \mathrm{DPI}+\mathrm{rOPN}$

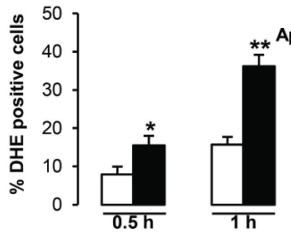

$\square$ Control

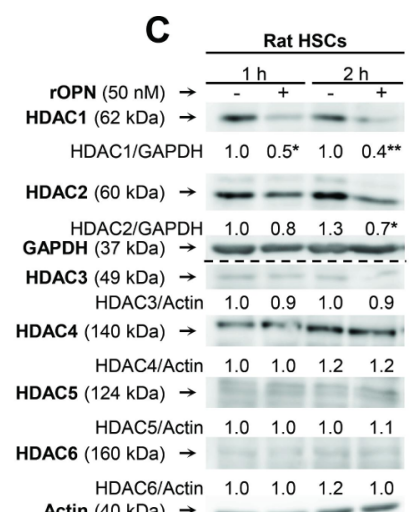

Actin $(40 \mathrm{kDa}) \rightarrow \quad 1.0$

$\vec{E}$

Rat HSCs

pocynin $(500 \mathrm{nM}, 7 \mathrm{~h}) \rightarrow-\quad+\quad+$ $\operatorname{rOPN}(50 \mathrm{nM}, 6 \mathrm{~h}) \rightarrow-+\quad+$

HDAC1 $(62 \mathrm{kDa}) \rightarrow$

HDAC1/Calnexin $1.0 \quad 0.5^{* *} 0.9 \quad 0.9^{\circ}$

HDAC2 $(60 \mathrm{kDa}) \rightarrow=--=$

$\begin{array}{lllll}\text { HDAC2/Calnexin } & 1.0 & 0.6^{*} & 1.2 & 1.0^{\circ}\end{array}$

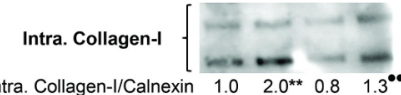

$\begin{array}{lllll}\text { Intra. Collagen-l/Calnexin } & 1.0 & 2.0^{* *} & 0.8 & 1.3^{\circ *}\end{array}$

Extra. Collagen-I

Extra. Collagen-l/Calnexin $1.0 \quad \overline{2.0^{* *}} 1.2 \quad 1.4^{\circ}$

Total Collagen-l/Calnexin $2.0 \quad 4.0^{* *} 2.0 \quad 2.7^{\circ \bullet}$

Actin $(42 \mathrm{kDa}) \rightarrow-$

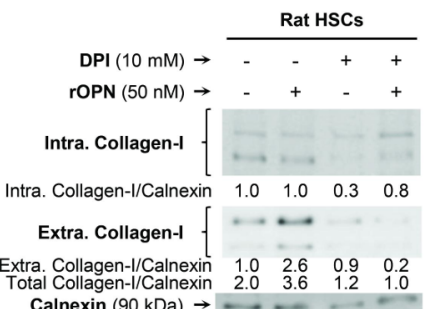

Figure 6 rOPN activates NOX and inhibits HDACs1/2 promoting HMGB1 acetylation and translocation along with collagen-I up-regulation in HSCs. Rat HSCs were treated with rOPN for $6 \mathrm{~h}$. Immunoprecipitation of intracellular HMGB1 and immunoblotting for acetylated lysines (A). Rat HSCS were treated with rOPN for $2 \mathrm{~h}$. Western blot analysis for PCAF and p300 (B). Rat HSCs were treated with rOPN for 1 and $2 \mathrm{~h}$. Western blot analysis for HDACs1-6 (C). NOX activity in rat HSCs treated with rOPN for $6 \mathrm{~h}$ alone or pretreated for $0.5 \mathrm{~h}$ with apocynin or DPI, two NOX inhibitors. The percentage of DHE positive cells was measured by flow cytometry as an indirect measurement of $\mathrm{O}_{2}{ }^{-}$production (D). Rat HSCs were treated with rOPN for $6 \mathrm{~h}$ in the presence or absence of apocynin or DPI. Western blot analysis of HDACs $1 / 2$ along with intra- and extracellular collagen-I (E). The results from the western blot analysis are corrected by the specific loading control and are expressed as fold-change of the controls, which are assigned a value of 1 and are mean values $\pm S E M ; n=3 /$ group in experiments performed in triplicate four times. ${ }^{*} \mathrm{P}<0.05,{ }^{* *} \mathrm{p}<0.01$ and ${ }^{* * *} \mathrm{p}<0.001$ for rOPN versus control; $\bullet p<0.05$ and $\bullet \bullet p<0.01$ for cotreated versus rOPN. 


\section{(2) \\ OPEN ACCESS}

Open access This is an open access article distributed in accordance with the Creative Commons Attribution Non Commercial (CC BY-NC 4.0) license, which permits others to distribute, remix, adapt, build upon this work noncommercially, and license their derivative works on different terms, provided the original work is properly cited, appropriate credit is given, any changes made indicated, and the use is non-commercial. See: http://creativecommons.org/licenses/by-nc/ 4.0\%

(c) Author(s) (or their employer(s)) 2020. Re-use permitted under CC BY-NC. No commercial re-use. See rights and permissions. Published by BMJ.

Gut 2020;69:e2. doi:10.1136/gutjnl-2015-310752corr1

(A) Check for updates 